\title{
FATCA AND CRS COMPLIANCE: BRAZIL'S TREND TOWARDS AUTOMATIC EXCHANGE OF INFORMATION
}

\author{
José Rubens Scharlack*
}

\begin{abstract}
Although legislation allowing tax authorities to have access to banking information of taxpayers be in force for several years and Brazil be entering into agreements providing for even automatic exchange of taxpayers' banking information, the extent of Brazil's constitutional protection of banking secrecy is not yet clear and, accordingly, so is reliability of Brazil's FATCA and CRS compliance. Under Brazil's OECDoriented Double Tax Treaties, banking secrecy is not regarded as broken because of Contracting States sharing taxpayers' confidential information, which must be kept secret. Also, under FATCA's Intergovernmental Agreement, account holders who do not comply with its due diligence standards shall be subject to account termination or to the 30\% American withholding taxation. Finally, in order to reach full CRS compliance, Brazil must have rules providing for proper financial institutions' reporting levels. Such rules exist and can be found in Complementary Law 105/2001, but a higher command, set forth in the Federal Constitution, might oppose a formidable barrier to the intended automatic exchange of banking information. So far, the Supreme Federal Court (STF) considers banking secrecy as included in the constitutional protection of intimacy, private life and data secrecy. However, STF has been slowly building new, divergent arguments on this matter, exploring the differences between "secrets of being" (a person's thoughts, ideas and emotions) versus "secrets of having" (a person's assets, income and economic activities) and also between the transfer of confidential information from one authority to another versus the leak of such information to the public. A close analysis of the respective precedents shows that banking data secrecy's judicial protection may come to an end soon. Only if STF concludes such shift of understanding and aligns with OECD's position on the matter, will Brazil's road towards international tax enforcement be safely open.
\end{abstract}

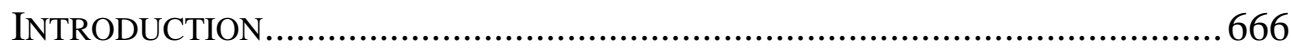

I. The EXCHANGE OF INFORMATION IN BRAZIL's 32 DOUBLE TAX TREATIES

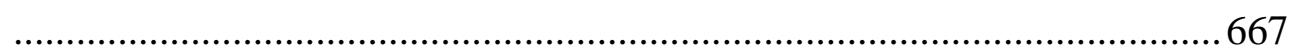

II. BRAZIL's CURRENT LEVEL OF FATCA IMPLEMENTATION.....................668

III. BRAZIL's CURRENT STATUS ON CRS ADHESION ................................669

IV. BANKING SECRECy CONSTITUTIONAL PROTECTION ............................670

CONCLUSION .......................................................................... 674

\footnotetext{
* attorney in Brazil, founding partner of Rodante \& Scharlack Advogados-RSCH. Research fields: Domestic and Cross-border Tax Law.
} 


\section{INTRODUCTION}

Although legislation allowing tax authorities to have access to banking information of taxpayers be in force for several years ${ }^{1}$ and Brazil's representatives be signing agreements allowing even automatic exchange of information—among which banking information —of taxpayers, these have been resisting and carrying on judicial litigations against such disclosures. For the sake of legal certainty, this situation demands a final and binding conclusion from the Brazilian highest constitutional Court. So far, however, the extent of Brazil's constitutional protection of banking secrecy is not clear and, therefore, so is reliability of FATCA and CRS compliance.

The graphic below gives a better idea of the problem explored in this article:

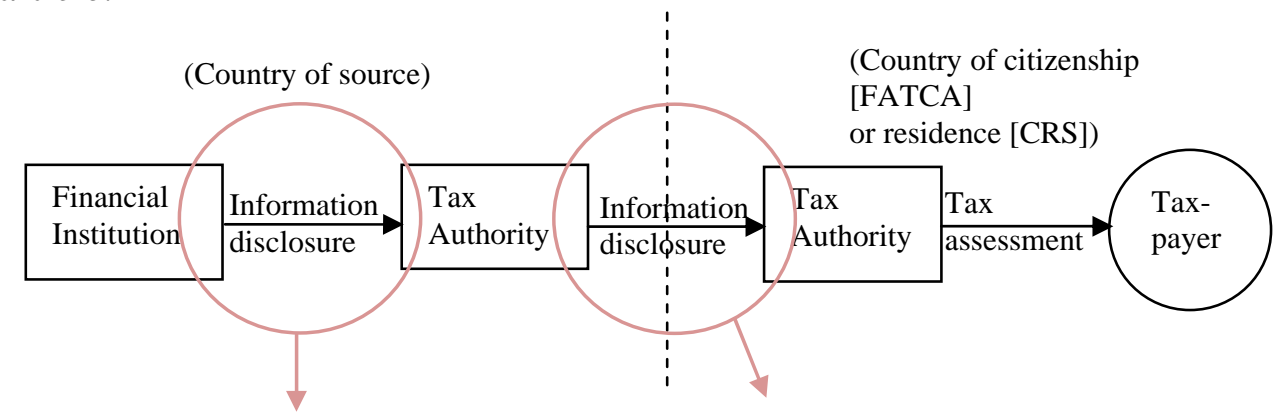

- Data secrecy protected by article 5, item XII, • Model 1 IGA (signed between Brazil of the Federal Constitution; $\mathbf{X}$ and USA in 2014);

- Article 26 of the OECD Model

- Automatic disclosure demanded by article 5 of Complimentary Law 105/2001 and by article 2 of Decree 4489/2002. Convention (present in Brazil's 32 DTT's);

- Multilateral Convention on Mutual Administrative Assistance in Tax Matters (signed by Brazil in 2011).

On the "second leg" (between the Brazilian and foreign tax authorities), there is a whole international net of legally binding treaties and conventions providing for the disclosure of taxpayers' banking information, which, however, depends on the enforceability and reliability of the "first leg" (between the Brazilian financial institution and the Brazilian tax authority), where the problem lies: although there be specific and mandatory legislation for even automatic disclosure of taxpayers' banking information, such

\footnotetext{
${ }^{1}$ In Brazil, both tax enforcement and information exchange have progressively relied on electronic systems. Given the fact that Brazil is a federation, federal, state and municipal tax authorities have exchanged information provided by the taxpayers by means of periodic electronic (federal, state and municipal) tax returns. Also electronic audits have taken place, mainly on the federal level. Information inconsistencies between the different tax returns have given place to both electronic and physical tax audits.
} 
disclosure (and legislation) is arguably unconstitutional and has been successfully challenged (so far) by individuals and corporations.

\section{ThE EXCHANGE OF INFORMATION IN BRAZIL'S 32 Double TAX TREATIES}

Brazil has currently in force 32 (thirty-two) treaties to avoid double taxation. Those are the ones signed with Japan (internalized into the Brazilian legislation in 1967), France (internalized in 1972), Belgium (1973), Denmark (1974), Spain (1976), Sweden (1976), Austria (1976), Luxembourg (1980), Italy (1981), Norway (1981), Argentina (1982), Canada (1986), Ecuador (1988), The Philippines (1991), Slovak Republic (1991), Czech Republic (1991), Hungary (1991), South Korea (1991), The Netherlands (1991), India (1992), China (1993), Finland (1998), Portugal (2001), Chile (2003), Israel (2005), Ukraine (2006), South Africa (2006), Mexico (2006), Peru (2009), Turkey (2013), Trinidad Tobago (2014) and Venezuela (2014).

It is important to remind that, although being a non-OECD country, Brazil has used the OECD Model Tax Convention as a base for its treaties. Therefore, the treaties' clause on information exchange has undergone a similar metamorphosis to Article 26 of the Model Tax Convention: later treaties (especially those incorporated into domestic legislation after 2000) tend to have a much broader and compelling clause on exchange of information than older ones.

Also, it is worth pointing that, under these treaties, banking secrecy does not seem to be a problem for the exchange of information between tax authorities. The respective clause seems to be construed in a way that banking secrecy would not be regarded as broken by the mere disclosure of the information between the Contracting States, since, under its provisions, the disclosed information must be kept secret and be used only by the competent authorities. Furthermore, the latest version of Article 26 of the Model Tax Convention (reproduced, for example, in Brazil's treaty with Turkey) states, rather clearly, on paragraph 5, that a Contracting State shall not "decline to supply information solely because the information is held by a bank, other financial institution, nominee or person acting in an agency or a fiduciary capacity or because it relates to ownership interests in a person".

It seems, therefore, that the issue of banking secrecy has been addressed by the double taxation treaties, although in different shapes and to unequal extents throughout time. Nevertheless, the vast majority of treaties do not provide for automatic exchange of information. Only more recently 
such has been adequately addressed, via the FATCA and CRS approaches.

Finally, all of the treaties signed by Brazil are clear as to information exchange shall not be done in a way that conflicts with Brazilian internal laws. And, as it is known, the highest law of all is the Constitution.

\section{BRAZIL’s CURRENT LEVEL OF FATCA IMPLEMENTATION}

In September 23rd, 2014, Brazil has signed the Model 1 Reciprocal Intergovernmental Agreement (IGA) with the United States of America. Such IGA follows another agreement, signed in 2007 (and approved by the Congress in March, 2013), for the exchange of information between the two countries' tax authorities. The IGA shall enter into force as soon as it is ratified by the Brazilian National Congress and shall ease the local application of the Foreign Account Tax Compliance Act (FATCA), which, so far, depends on the individual decision of each financial institution in Brazil.

Long before Brazil's adhesion to the IGA, however, the Brazilian Federation of Banks (FEBRABAN) had been advising financial institutions to make a fast decision on whether or not to comply with FATCA. According to FEBRABAN, global events such as 2014 FIFA World Cup and the 2016 Olympic Games, alongside with domestic economic growth and the ascension of non-Brazilian investors and working force into the country, would be key factors pro-FATCA compliance.

FATCA has, indeed, been affecting the business of Brazilian financial institutions for some years already. From all industries within the financial sector, commercial banks are the ones more heavily affected. Most of them had already adhered to FATCA by the time Brazil signed the IGA. According to FEBRABAN, although FATCA be the outcome of a tax rule, the greatest efforts for its implementation are on the operational level, requiring structural and systemic changes. As a matter of fact, FATCA gave final shape to the already existing Anti-Money-Laundering (AML) and Know-Your-Customer (KYC-and similar: KYE, KYS, KYP etc.) initiatives organized by FEBRABAN in light of changes made in 2012 to the Brazilian AML Law (Law 9,613/1998, as amended by Law 12,683/2012).

On the other hand, given the fact that all bank accounts-at least the ones held in participating Foreign Financial Institutions (FFI's) — shall be subject to due diligences in order for them to be regarded as whether "US Accounts" or not, and that those account holders who do not comply with the due diligence requests of the bank (the 'recalcitrant' ones) shall be 
subject to account termination or to the $30 \%$ American withholding taxation (WHT), a number of conflicts (including judicial ones) may arise, in regards to compliance with both reporting and tax withholding obligations, due to data secrecy constitutional protection in Brazil.

\section{BRAZIL’s CURRENT STATUS ON CRS ADHESION}

The Common Reporting and Due Diligence Standard (CRS), as part of OECD's, the G20's and the European Union's Standard for Automatic Exchange of Financial Account Information, has its legal base on Article 26 of OECD's Model Convention and on the Multilateral Convention on Mutual Administrative Assistance in Tax Matters (the "Multilateral Convention” ), article 6 of which reads:

Article 6-Automatic exchange of information

With respect to categories of cases and in accordance with procedures which they shall determine by mutual agreement, two or more Parties shall automatically exchange the information referred to in Article 4.

Therefore, as per article 6 of the Multilateral Convention and according to OECD's official guidance ${ }^{2}$

Automatic exchange under the Convention requires a separate agreement between the competent authorities of the parties, which can be entered into by two or more parties thus allowing for a single agreement with either two or more parties (with actual automatic exchange always taking place on a bilateral basis). Such a competent authority agreement then activates and 'operationalizes' automatic exchange between the participants.

Despite having signed the amended Multilateral Convention in November 2011, Brazil has not yet translated it into domestic law. Moreover, unlike other 61 (sixty-one) jurisdictions who have already signed the Multilateral Competent Authority Agreement (CAA) providing for actual automatic exchange of information, Brazil has not done so. It has not declined on automatic exchange of information either ${ }^{3}$, which leads to the conclusion that Brazil's full adherence to CRS is rather a matter of time than of choice ${ }^{4}$.

Finally, as it is with FATCA and the double taxation treaties, in order

\footnotetext{
${ }^{2}$ Standard for Automatic Exchange of Financial Account Information, OECD, 2014, at 8, item 14.

${ }^{3}$ As other 51 (fifty-one) jurisdictions have done. Please see https://thebanks.eu/articles/countrieswhich-will-not-automatically-exchange-account-information\#full_list_no_exchange.

${ }^{4}$ Automatic exchange of information has not been common in the international field for Brazil. However, there does not seem to be any cultural resistance to this kind of approach by the Brazilian bodies of administration, specially having in mind that it already occurs within the different levels of the federation.
} 
to fully implement CRS compliance, Brazil "must have rules in place that require financial institutions to report information consistent with the procedures contained" ${ }^{5}$ therein. Such rules exist and can be found in Complementary Law 105/2001, but, as it shall be seen below, a higher command, set forth in the Federal Constitution, might oppose a formidable barrier to such a flow.

\section{BANKING SECRECy CONSTItUTIONAL Protection}

According to the so far existing precedents of the Supreme Federal Court (STF), banking secrecy is considered to be included in the constitutional protection of intimacy, private life and data secrecy, set forth in article $5^{\text {th }}$, items $\mathrm{X}$ and XII, of the Brazilian Federal Constitution:

Art. 5th. (...)

$\mathrm{X}$ - intimacy, private life, honor and image of the people are sacred, being assured the right to indemnification for material or moral damages arising from its violation;

\section{(...)}

XII - the secrecy of mail and of telegraphic communication, of data and of telephone communication is sacred, safe, in the latter case, by judicial order, in the hypothesis and in the way set forth by law for the purposes of criminal investigation or criminal procedural proof;

Banking data secrecy has been regulated by Complementary Law $105 / 2001$, which ruled that banking data should only be disclosed in case of any illicit conduct (and specially in the case of terrorism, money laundering, crimes against the public administration and other relevant crimes), under judicial order or under command of the competent Brazilian tax authority within the proper administrative procedure. According to said law, the Central Bank of Brazil and the Securities Commission have full access to the existing banking data in Brazil and, despite having the obligation to hold confidentiality on the assessed information, are allowed to execute exchange information agreements with other audit bodies (including non-Brazilian ones).

It is also a fact that many Brazilian citizens and entities have successfully relied on banking secrecy to avoid disclosing unwanted information to Brazilian authorities. Indeed, ever since the Brazilian Constitution has passed, STF has regarded banking information as an example of the data protected by item XII of Article $5^{\text {th }}$, also covered by the protection of intimacy and private life mentioned by item $\mathrm{X}$ of the same

\footnotetext{
${ }^{5}$ Standard for Automatic Exchange of Financial Account Information, OECD, 2014, at 10, item 26.
} 
article. The precedent below ${ }^{6}$ gives a clear view of the mindset of our Supreme Court in the 2000's:

The breach of anyone's intimacy - whenever in the absence of a probable cause - reveals itself incompatible to the model established at the Constitution of the Republic, for the secrecy break cannot be manipulated, in an arbitrary way, by the Public Power or by its agents. If it were not this way, confidentiality break would be converted, illegitimately, in an instrument for general search, which would give to the State - despite the lack of concrete inditia - the power to rummage over other people's confidential records, in order to make possible, by means of the illicit use of an indiscriminate inquest (which not even the Judiciary can order), the access to data supposedly stained with legal-probating relevance, due to informative elements which could possibly be found.

The reason for the secrecy breach needs to be contemporary to the very legislative deliberation which determines it.

The demand for motivation - which must be contemporary to the act of the Parliamentary Inquiry Commission which orders the confidentiality breachqualifies as a premise of legal validity of the deliberation from such a legislative investigation body, and cannot be fulfilled later on, as of the rendering of information within a writ of mandamus. Precedents. (STF, Plenary, MS \# 23.8518, Rapporteur Minister Celso de Mello, judgement held in09/26/2001, unanimous decision)

However, during the time these precedents were being discussed and built within STF, some of the Ministers began do differentiate the kind of data which would in fact demand protection under constitutional principles. This initial discussion was first noticed in the following precedent, of 2006:

Data Confidentiality-Auditing Role of the Central Bank-ClearanceUnfeasibility. The auditing role of the Central Bank of Brazil does not contain the possibility of, within the administrative field, reaching banking data of account holders, clearing the secrecy foreseen at item XII of article 5th of the Federal Constitution. (STF, Plenary, RE \# 461.366-2, Rapporteur Minister Marco Aurélio, judgement held in 08/03/2007, majority decision)

The first Minister to inaugurate such new argumentative inquiry was Minister Carmen Lucia. Although she ultimately voted against the disclosure in casu, she made a very interesting distinction between the information pertaining to the person's inner emotions and thoughts (data related to the 'being'), possible of intimacy, private life and data secrecy constitutional protection, and the information related to the assets, income

\footnotetext{
${ }^{6}$ Please also refer to: STF, Plenary, RE\#418.416-8, Rapporteur Minister Sepúlveda Pertence, decision held in 05/10/2006, majority decision, and STF, Plenary, MS \# 22.801-6, Rapporteur Minister Menezes Direito, judgement held in 12/17/2007, unanimous decision.
} 
and economic activities of the person (data related to the 'having'), which should not be covered by secrecy because those assets, income and activities directly relate to the society and should rather be disclosed. An excerpt of her vote is transcribed below:

I have already expressed here that I distinguish, within item X of article 5th, to the effects of tax and banking secrecy, what the Portuguese distinguish between secrets of the 'being' and secrets of the 'having'. Secrets of the 'being' are, yes, absolute within the Constitution. What you are, think and feel are absolute secrets protected by the Constitution, because they refer to the life and dignity of each one. This has even been brought to the Supreme, for example, in cases of diseases, the individual is obliged, by a job, to take on an exam and the result goes public or is leaked from one company to another. This is absolute, because the individual may want or not to disclose his/her condition.

Secret of the 'having' is something which came to be in the Modern State, with the exacerbation of the individualism. From Portugal we inherited, until the beginning of last century, what was romantically called 'assets under the moonlight': everyone who was about to occupy a public position would have to show his/her assets, so that one knew who would occupy the public positions. In such a task, I have analyzed how, before, everything had to be clearer; and, today, we fight for transparency.

The very word candidate comes from candid, because the individual had to present what he had; and, since ancient Rome, he appeared in a white robe to show he/she had no moral stain a all. He showed all he had, including his body; Meaning that he had physical conditions to occupy that position. The so-called 'assets under the moonlight' were so that the one who candidated himself would show everything he had and, therefore, his conditions would be known by all. I believe these 'secrets of the having' to be relative.

Moreover, Minister Carlos Brito, who casted a divergent vote in this precedent, also inaugurated a concept that came to be better explored in later precedents: "one thing is to have access to data, another is to disclose such data, break the confidentiality of such data". To which he was echoed by Minister Sepulveda Pertence: "What is really concerning is the impunity of true breaches; that is, not the transfer of secrecy to a responsible authority, but the so-called leaking of confidential information."

Therefore, when the time came to issue a precedent on the constitutionality of Complementary Law 105/2001, specifically involving the transfer of taxpayer's data from Brazilian financial institutions to the Brazilian tax authorities, STF has issued a relevant precedent in 2010, considering such an unconstitutional data secrecy breach:

Data Secrecy-Clearance. As foreseen in item XII of article 5th of the Federal Constitution, the rule is the privacy as to mail, telegraphic 
communication, data and communication, being the exception-the breach of secrecy - submitted to the appreciation of an equidistant body-the Judiciaryand, even so, to the effect of criminal investigation and criminal lawsuit probation.

Banking Data Secrecy-Federal Revenue. Conflicts with the Letter of the Republic legal rule granting to the Federal Revenue-party to the legal-tax relationship - the clearance of the secrecy of data pertaining to the taxpayer. (STF, Plenary, RE \# 389.808, Rapporteur Minister Marco Aurélio, judgement held 12/15/2010, majority decision)

Such precedent, however, was issued by a partially empty Supreme Court (9 out of 11 Ministers) and at very close margin of votes (5 versus 4 ). Also, among the loosing votes, the arguments on "secrecy of being" versus "secrecy of having" and also on the lack of secrecy breach when information be transferred to the care of the competent inquiring authority instead of being disclosed to the general public, first arisen at RE \# 461.3662 , came back with renovated strength. The (loosing) votes of Ministers Dias Toffolli, Carmen Lucia and Carlos Britto are partially reproduced below:

Excerpt of Minister Dias Toffolli's vote:

Very well, in this sense my understandings is that here there is no secrecy breach. There is, actually, a transfer of secret data from one bearer who has the duty of confidentiality to another bearer who shall maintain the duty of such confidentiality. If he/she/it does not maintain it, will commit a crime and shall be held responsible.

\section{Excerpt of Minister Carmen Lucia’s vote:}

Mr. President, I also beg Minister Rapporteur's pardon, but, as I already voted in other occasions, I also do not see, here, aggression to fundamental rights, once it does not seem to me that there has been a breach of intimacy; once it is not authorized by law to make public, but only to transfer to another body of administration, for the fulfillment of the finalities of the Public Administration, those data. Therefore, it absolutely does not seem to me that there has been any unconstitutionality even to configure the need of an interpretation according to the Constitution.

I also think there is no way to fulfill the finalities of the State, especially of the Tax Administration, and even of the Criminal Law, in cases where there must be an investigation and punishment, if there is no access to such data, which, anyhow, are already within the knowledge of the financial institutions who are not even State.

Excerpts of Minister Carlos Britto’s vote:

Therefore, it seems to me that the conjugation of item XII with item X of the Constitution supports the thesis in which what is prohibited is not the access to data, but the secrecy breach, is the leaking of the data. It is the leak, the 
disclosure. And, in this case, the applicable laws, when referring to the transfer of secret data, it is clear that they impose to the public body the non-disclosure clause, the breach of which characterizes the commitment of a crime.

On the other hand, this kind of interpretation which arises from Minister Toffoli's vote makes, implicitly, a very valuable distinction to Minister Carmen Lucia and to me. Whenever I can, as well as Minister Carmen Lucia, I make a differentiation between 'being' and 'having'.

What Law takes more and more into consideration, notably Constitutional Law, is the preservation of data relating to 'being'.

(...)

The data of 'having', of assets, income, economic activities, in their objectiveness, they are all oriented towards an overture. The future shall not preserve but the data of the 'being'. Data of the 'having' shall be progressively wide open, because assets and income are gained from the society, and society needs to know the means by which these goods, currency convertible, were obtained and in which they consist. Such is of the natural logic of a society who makes of transparency and visibility true pillars of democracy.

\section{CONCLUSION}

Probably unlike other countries, Brazil's full adherence to FATCA and CRS, or, in a broader approach, to automatic exchange of information for tax purposes, demands more than treaties and internal laws. It demands that banking secrecy judicial protection be removed.

In this sense, the constitutional protection of taxpayer's banking information from tax authorities, although still in force, has been receiving more and more divergent votes within the STF. Indeed, as shown above, a close analysis of the respective precedents points to the probable end of judicial protection of banking data secrecy in the near future. Moreover, old preliminary injunctions have been reverted ${ }^{7}$ within the STF and overruled in newer requests ${ }^{8}$, which shows that the Supreme Court understands there is a new balance to be reached on this subject.

Such judicial resistance is the last standing force against international automatic exchange of information for tax purposes. Should STF continue with its progressive shift of understanding and comprehend that there is no clause within the Federal Constitution providing for "secrecies of the having” and follow OECD's understanding that careful transfer of secrecy data between competent authorities is not the same as secrecy breach, then taxpayers shall no longer be able to hide their assets behind a court order

\footnotetext{
${ }^{7}$ V.g. RE 387604, decision of 02/23/2011, AGA 662902, decision of 06/21/2011, RE 555112, decision of 09/22/2011 and AGA 714857, decision of 11/03/2011.

${ }^{8}$ V.g. MS 33340, decision of 05/26/2015.
} 
and refrain from taxation, be it in Brazil or in their citizenship (FATCA) or residence (CRS) jurisdiction. The road will be open for the final legislative initiatives (signature of the Multilateral CAA and incorporation of the Model 1 IGA and the Multilateral Convention into domestic law) to contribute to Brazil's inclination towards international tax enforcement. 